Research Paper

\title{
Reduced Risk of Human Lung Cancer by Selective Cyclooxygenase 2 (Cox-2) Blockade: Results of a Case Control Study
}

\author{
Randall E. Harris, Joanne Beebe-Donk, Galal A. Alshafie \\ The Ohio State University College of Medicine \& School of Public Health, A150B Starling-Loving Hall, 320 W. 10th Avenue, \\ Columbus, $\mathrm{OH} 43210$, USA \\ Correspondence to: Prof. Randall E. Harris, Ph: 614-293-3913, Fax: 614-293-3937 Email: Harris.44@osu.edu
}

Received: 2007.05.10; Accepted: 2007.06.12; Published: 2007.06.13

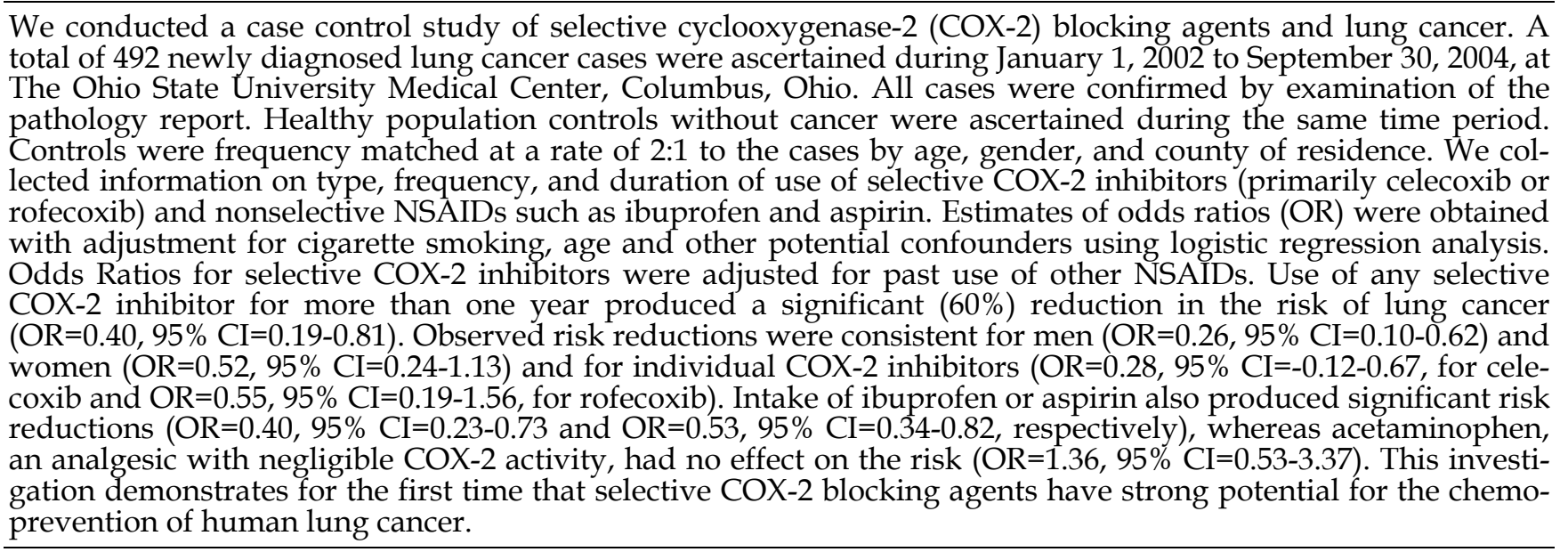

Key words: Cyclooxygenase-2 (COX-2), lung cancer, Nonsteroidal anti-inflammatory drugs (NSAIDs), chemoprevention

\section{INTRODUCTION}

The American Cancer Society estimates that more than 1.4 million new cases of invasive cancer will be diagnosed during 2006 in the United States, and more than 564,000 Americans will die from cancer [1]. When age-adjusted death rates are considered, cancer has surpassed heart disease and is now the leading cause of death among American women and men under age 85. The majority (about $60 \%$ ) of cancer deaths are attributable to four major cancer types: lung, breast, prostate, and colon. Lung cancer is by far the leading cause of cancer death in both men and women, causing nearly 93,000 deaths in men and 82,000 deaths in women every year. The number of deaths due to lung cancer exceeds that of breast cancer, prostate cancer, and colon cancer combined. Despite intensive efforts aimed primarily at early detection and therapy of lung cancer, its high mortality rates have persisted for several decades. Innovative research efforts must therefore be redirected towards chemoprevention of the early stages of lung carcinogenesis.

Nonsteroidal anti-inflammatory drugs (NSAIDs) and cancer

The epidemiologic literature provides consistent evidence that regular intake of NSAIDs with non-selective activity against cyclooxygenase- 2 (COX-2) protects against the development of many types of neoplasms including lung cancer $[2,3,4)]$ Notably, a recent case control study documented significant effects of selective COX-2 inhibitors (celecoxib and rofecoxib) against breast cancer [5] Nevertheless, there are currently no other published studies of selective COX-2 inhibitors and cancer.

\section{Lung Cancer and NSAIDs}

The early preclinical studies of Schuller et al. [6] and Castonguay and Rioux $[7,8]$ provide convincing evidence that inhibition of prostaglandin biosynthesis by various NSAIDs reduces the development of chemically induced pulmonary adenocarcinoma. Wolf et al. [9], Hida et al. [10], Koki et al. [11], and other investigators have observed that COX-2 is over-expressed in 70-90\% of human pulmonary adenocarcinomas and other non-small cell lung cancers. Additional molecular studies by Schuller and colleagues $[12,13,14,15]$ determined that lung carcinogenesis is linked to the stimulation of beta-adrenergic receptors by nitrosamines and possibly other tobacco carcinogens. They have identified a novel mechanism by which the nitrosamine, NNK, modulates the ara- 
chidonic acid cascade and DNA synthesis through signal transduction involving both beta- 1 and beta-2 adrenergic receptors. Notably, this effect is inhibited by administration of NSAIDs [12].

Early prospective epidemiologic investigations by Peto et al. [16] and Schreinemachers and Everson [17] suggested that regular aspirin intake produced a significant reduction in lung cancer risk. Subsequently, other investigators have also observed protective effects of aspirin and other NSAIDs against the development of lung cancer [18, 19] and a recent meta-analysis of eleven published epidemiologic studies found that regular intake of NSAIDs produced a $36 \%$ reduction in the risk of lung cancer [3].

In one case control study designed to specifically compare the use of NSAIDs between smokers who developed lung cancer (smoking cases) and control subjects who also smoked, regular intake of NSAIDs with non-selective COX-2 activity (primarily aspirin and ibuprofen) produced a $69 \%$ reduction in the relative risk of lung cancer [18]. In contrast, acetaminophen, a comparator analgesic without COX-2 activity, had no effect on the risk of lung cancer. These findings clearly suggest that COX-2 blockade inhibits lung carcinogenesis among smokers.

\section{Rationale for epidemiologic investigation of selective COX-2 inhibitors}

Taken together, the above results provide the background and significance to conduct further epidemiologic studies to examine the chemopreventive potential of selective COX-2 blockade against lung cancer and other forms of malignancy. Significant use of selective cyclooxygenase-2 (COX-2) blocking agents such as celecoxib (Celebrex) and rofecoxib (Vioxx) prescribed for the treatment of arthritis during 1999 to September 30, 2004 (the date of the recall of Vioxx from the worldwide marketplace by its manufacturer, Merck) facilitates epidemiologic investigations to illuminate their chemopreventive effects against major cancers.

We therefore designed a case control investigation to estimate and test odds ratios as measures of preventive effects of selective COX-2 agents against lung cancer, the deadliest of all malignancies. Specifically, we examined the chemopreventive effects of selective COX-2 inhibitors (celecoxib, valdecoxib, rofecoxib, and meloxicam) against invasive lung cancer utilizing a case control epidemiological design. Effects of COX-2 blockade were quantified in comparisons of cancer cases with healthy controls. This investigation was designed to collect initial critical evidence on the relative potential of selective COX-2 blocking agents in the chemoprevention of cancers of the lung.

\section{RESEARCH DESIGN AND METHODS}

\section{Experimental design and population studied}

The experimental design is a retrospective case control study of lung cancer with frequency matching of cases and control subjects for age, gender, and location of residence. We studied 492 cases of invasive lung cancer with histological verification based upon review of the pathology records, and cancer-free controls frequency matched to the cases at a 2:1 ratio. Among the case series, $84 \%$ had non-small cell lung cancers (43\% adenocarcinomas, $35 \%$ squamous cell carcinomas and $6 \%$ large cell carcinomas), $11 \%$ had small cell carcinomas, and $6 \%$ had other histologic cell types. We utilized the mammography screening service and the prostate screening service for ascertainment of healthy female and male control subjects, respectively, without cancer. The 984 controls were ascertained with frequency matching to the cases at a rate of 2:1 on age, gender, race, and place (county) of residence. The protocol was approved by the Internal Review Board of The Ohio State University Medical Center.

\section{Data collection}

Critical information on exposure to selective COX-2 inhibitors, non-selective NSAIDs, and other factors was obtained by trained medical personnel at the time of cancer diagnosis for cases or screening visit for controls. We collected accurate and comprehensive information on the type, frequency of use, dose, and duration of use of both prescription and non-prescription drugs. Other data variables collected consisted of demographic characteristics, height, weight, menstrual and pregnancy history for women, family history of cancer, comprehensive information on cigarette smoking, alcohol intake, pre-existing medical conditions (arthritis, chronic headache, cardiovascular conditions including hypertension, angina, ischemic attacks, stroke, and myocardial infarction, lung disease, and diabetes mellitus), and medication history including over the counter and prescription NSAIDs, and exogenous hormones. Regarding selective COX-2 inhibitors and other NSAIDs, the use pattern (frequency, dose, and duration), the type, such as celecoxib, valdecoxib, rofecoxib, meloxicam, aspirin, ibuprofen, naproxen, indomethacin, etc, were recorded. Data on the related analgesic, acetaminophen were collected for comparison with selective COX-2 inhibitors and other NSAIDs.

\section{Biostatistical analysis}

Effects of the selective COX-2 inhibitors as a group were quantified by estimating odds ratios and their 95\% confidence intervals. Odds ratios were adjusted for age and other factors by logistic regression analysis [20,21, 22]. In addition, odds ratios for COX-2 inhibitors were adjusted for past years of use of other types of NSAIDs (aspirin, ibuprofen, or naproxen). Data were stratified by gender, ethnicity, and by cancer risk factors (e.g., smokers and non-smokers) and odds ratios estimated within subgroups and checked (by chi square tests) for internal consistency, effect modification, and confounding. Adjusted estimates were obtained for specific types of compounds, e.g, celecoxib and rofecoxib. Similar methods were applied for the non-selective NSAIDs, regular (325 mg) aspirin and ibuprofen, low dose (81 $\mathrm{mg})$ aspirin, and the analgesic, acetaminophen. 


\section{RESULTS}

Pertinent characteristics of the cases and controls are given in Table 1. As expected, cases and controls had similar distributions of gender, age, race, and education, whereas the cases exhibited a marked excess of chronic cigarette smoking. The strong etiologic association of lung cancer with chronic smoking is reflected by the increasing dose response in the odds ratio with greater pack years of exposure $(\mathrm{OR}=17.3$, 95\% $\mathrm{CI}=10.8-27.6$ for $1-19$ pack years and $\mathrm{OR}=52.4$, $95 \% \mathrm{CI}=34.8-71.9$ for 20 or more pack years). The cases also reported a slightly higher frequency of upper respiratory cancers among first and second degree relatives, and a reduction in body mass index at the time of diagnosis.

Table 1. Characteristics of lung cancer cases and controls.

\begin{tabular}{|c|c|c|}
\hline Characteristic ${ }^{a}$ & Cases $(\mathrm{N}=492)$ & Controls $(\mathrm{N}=984)$ \\
\hline Gender (female) & $40.4 \%$ & $40.3 \%$ \\
\hline \multicolumn{3}{|l|}{ Age (yrs) } \\
\hline$<50$ & $12 \%$ & $13 \%$ \\
\hline $50-65$ & 35 & 34 \\
\hline$>65$ & 53 & 53 \\
\hline Mean (SEM) & $64.4(0.5)$ & $64.1(0.5)$ \\
\hline \multicolumn{3}{|l|}{ Race } \\
\hline Caucasian & $87 \%$ & $89 \%$ \\
\hline All Other & 13 & 11 \\
\hline \multicolumn{3}{|l|}{ Education } \\
\hline$\leq 12$ yrs & $91 \%$ & $88 \%$ \\
\hline$>12$ yrs & 9 & 12 \\
\hline \multicolumn{3}{|l|}{ Family History } \\
\hline Positive & $17 \%$ & $12 \%$ \\
\hline Negative & 83 & $88(\mathrm{p}<0.05)$ \\
\hline \multicolumn{3}{|l|}{ Body Mass (BMI) } \\
\hline $\mathrm{BMI} \leq 22$ & $14 \%$ & $6 \%$ \\
\hline BMI 22-25 & 53 & 37 \\
\hline BMI 26-29 & 19 & 28 \\
\hline $\mathrm{BMI} \geq 30$ & 13 & $29(\mathrm{p}<0.01)$ \\
\hline Mean (SEM) & $25.7(0.9)$ & $28.3(0.7)$ \\
\hline \multicolumn{3}{|l|}{ Chronic Smoking } \\
\hline None & $6 \%$ & $72 \%$ \\
\hline 1-19 pack-years & 17 & 12 \\
\hline$\geq 20$ pack-years & 77 & $16(\mathrm{p}<.0001)$ \\
\hline \multicolumn{3}{|l|}{ Alcohol Intake } \\
\hline None & $52 \%$ & $47 \%$ \\
\hline 1-2 drinks per week & 26 & 25 \\
\hline$>2$ drinks per week & 22 & 28 \\
\hline
\end{tabular}

a Family History: lung cancer or other upper respiratory cancer among first or second degree relatives; Body Mass Index $=$ weight $(\mathrm{kg}) / \mathrm{ht}{ }^{2}(\mathrm{~m})$.

Risk estimates (odds ratios) for selective COX-2 inhibiting agents and other types of NSAIDs are presented in Table 2. It is important to note that all estimates are adjusted for a measure of the predominant risk factor for lung cancer, pack years of cigarette smoking. Furthermore, the odds ratios for COX-2 inhibitors are adjusted for past years of use of nonselective NSAIDs. The duration of exposure was up to 7 years for COX-2 inhibitors and more than 10 years for the non-selective NSAIDs. Daily intake of selective COX-2 inhibitors for two years or more produced a significant reduction (60\%) in the risk of lung cancer
$(\mathrm{OR}=0.40,95 \% \mathrm{CI}=0.19-0.81)$.

Significant risk reductions were also observed for the intake of two or more pills per week of regular aspirin $(\mathrm{OR}=0.53,95 \% \mathrm{CI}=0.34-0.82)$, and ibuprofen or naproxen $(\mathrm{OR}=0.40,95 \% \mathrm{CI}=0.23-0.73)$. Exposure to aspirin, ibuprofen, naproxen or a selective COX-2 inhibitor produced a significant reduction in the risk $(\mathrm{OR}=0.47,95 \% \mathrm{CI}=0.33-0.67)$. The effect of baby $(81 \mathrm{mg})$ aspirin was marginally significant $(\mathrm{OR}=0.74, \mathrm{P}<0.07)$ whereas acetaminophen use did not significantly influence the relative risk of lung cancer.

Since smoking is such an overwhelming risk factor for lung cancer, we also stratified the data on smoking status and derived separate estimates by smoking status. Estimated risk reductions for the selective COX-2 inhibitors were similar for chronic smokers $(\mathrm{OR}=0.24,95 \% \mathrm{CI}=0.12-0.45)$ and nonsmokers $(\mathrm{OR}=0.50,95 \% \mathrm{CI}=0.22-1.12)$. Estimates were also similar for women $(\mathrm{OR}=0.52,95 \% \mathrm{CI}=0.24-1.13)$ and men $(\mathrm{OR}=0.26,95 \% \mathrm{CI}=0.10-0.62)$ and for subjects who reported a past history of arthritis (OR $=0.40,95 \%$ $\mathrm{CI}=0.14-1.18)$ and those who did not $(\mathrm{OR}=0.38,95 \%$ $\mathrm{CI}=0.17-0.86$ ). Furthermore, odds ratios derived by histologic cell type were also similar, e.g., the risk reduction for pulmonary adenocarcinoma $(\mathrm{OR}=0.44$, $95 \% \mathrm{CI}=21=0.93$ ) was similar to that for other non-small cell lung cancer $(\mathrm{OR}=0.33,95 \%$ $\mathrm{CI}=0.15-0.74)$.

Table 2. Odds ratios with $95 \%$ confidence intervals for lung cancer and selective cyclooxygenase-2 (COX-2) inhibitors, and over the counter nonsteroidal anti-inflammatory drugs (OTC NSAIDS).

\begin{tabular}{|c|c|c|c|}
\hline Compound & $\begin{array}{l}\text { Number } \\
\text { of Cases }\end{array}$ & $\begin{array}{l}\text { Number } \\
\text { of Con- } \\
\text { trols }\end{array}$ & $\begin{array}{c}\text { Multivariate } \\
\text { OR }^{d}(95 \% \text { CI })\end{array}$ \\
\hline None/Infrequent Use ${ }^{a}$ & 315 & 506 & 1.00 \\
\hline $\begin{array}{l}\text { Any NSAID (aspirin, } \\
\text { ibuprofen, naproxen, or } \\
\text { COX-2 inhibitor) }\end{array}$ & 106 & 320 & $\begin{array}{c}0.47 \\
(0.33-0.67)\end{array}$ \\
\hline COX-2 Inhibitors ${ }^{b}$ & 22 & 71 & $\begin{array}{c}0.40 \\
(0.19-0.81)\end{array}$ \\
\hline \multicolumn{4}{|l|}{ OTC NSAIDsc } \\
\hline Aspirin & 60 & 148 & $\begin{array}{c}0.53 \\
(0.34-0.82)\end{array}$ \\
\hline Ibuprofen/Naproxen & 24 & 101 & $\begin{array}{c}0.40 \\
(0.23-0.73)\end{array}$ \\
\hline Acetaminophen & 18 & 25 & $\begin{array}{c}1.36 \\
(0.55-3.37)\end{array}$ \\
\hline Baby Aspirin & 53 & 133 & $\begin{array}{c}0.74 \\
(0.50-1.11)\end{array}$ \\
\hline
\end{tabular}

a No use of any NSAID or analgesic or infrequent use of no more than one pill per week for less than one year;

b COX-2 inhibitors include celecoxib, rofecoxib, valdecoxib, or meloxicam used daily for two years or more.

c Over the counter (OTC) NSAIDs/analgesics used at least two times per week for two years or more.

${ }^{\mathrm{d}}$ Multivariate odds ratios are adjusted for continuous variables (pack years of cigarette smoking, age and body mass) and categorical variables (gender, ethnicity, family history, arthritis and alcohol intake). Odds ratios for COX-2 inhibitors are also adjusted for past use of NSAIDs.

Table 3 presents risk estimates for individual se- 
lective COX-2 inhibitors (celecoxib and rofecoxib) plus dose-response data for aspirin and ibuprofen. Daily use of either $200 \mathrm{mg}$ celecoxib or $25 \mathrm{mg}$ rofecoxib for at least two years produced similar risk reductions $(72 \%$ and $45 \%$ respectively). The trend data for OTC compounds suggests that $325 \mathrm{mg}$ aspirin or $200 \mathrm{mg}$ ibuprofen also produced significant risk reductions when taken at least every other day for at least five years.

Table 3. Odds ratios for lung cancer by dose, frequency, and duration of exposure to celecoxib, rofecoxib, aspirin, and ibuprofen.

\begin{tabular}{|c|c|c|c|c|c|}
\hline Compound ${ }^{a}$ & Dose & Cases & Controls & $\begin{array}{c}\text { Frequency } \\
\text { of Use }\end{array}$ & $\begin{array}{c}\text { Multivariate } \\
\text { OR }^{b} \\
(95 \% \text { CI })\end{array}$ \\
\hline Reference & 0 & 315 & 506 & $\mathrm{~N} / \mathrm{A}$ & 1.00 \\
\hline Celecoxib & $\begin{array}{l}200 \\
\mathrm{mg}\end{array}$ & 10 & 36 & Daily & $\begin{array}{c}0.28 \\
(0.12-0.67)\end{array}$ \\
\hline Rofecoxib & $\begin{array}{l}25 \\
\mathrm{mg}\end{array}$ & 10 & 35 & Daily & $\begin{array}{c}0.55 \\
(0.19-1.56)\end{array}$ \\
\hline \multirow[t]{3}{*}{ Aspirin } & $\begin{array}{l}325 \\
\mathrm{mg}\end{array}$ & 28 & 24 & 1-3 weekly & $\begin{array}{c}1.43 \\
(0.73-2.80)\end{array}$ \\
\hline & & 32 & 124 & $>3$ weekly & $\begin{array}{c}0.36 \\
(0.22-0.58)\end{array}$ \\
\hline & & & & & $\begin{array}{c}\text { trend } \\
(p<0.05)\end{array}$ \\
\hline \multirow[t]{3}{*}{ Ibuprofen } & $\begin{array}{l}200 \\
\mathrm{mg}\end{array}$ & 8 & 35 & 1-3 weekly & $\begin{array}{c}0.57 \\
(0.23-1.39)\end{array}$ \\
\hline & & 16 & 66 & $>3$ weekly & $\begin{array}{c}0.36 \\
(0.19-0.66)\end{array}$ \\
\hline & & & & & $\begin{array}{c}\text { trend } \\
(p<0.01)\end{array}$ \\
\hline
\end{tabular}

aMinimum duration of exposure: 2 years for celecoxib or rofecoxib, 5 years for aspirin or ibuprofen.

bMultivariate odds ratios are adjusted for continuous variables (pack-years of cigarette smoking, age and body mass) and categorical variables (gender, ethnicity, family history, arthritis and alcohol intake). Odds ratios for COX-2 inhibitors are also adjusted for past use of NSAIDs.

\section{DISCUSSION}

This is the first epidemiologic investigation to observe a significant risk reduction in human lung cancer due to intake of selective COX-2 inhibitors. Standard daily dosages of celecoxib $(200 \mathrm{mg})$ or rofecoxib (25 mg) taken for two or more years produced a statistically significant risk reduction (60\%). Comparator NSAIDs with non-selective COX-2 activity (325 mg aspirin, $200 \mathrm{mg}$ ibuprofen or $250 \mathrm{mg}$ naproxen) also produced significant risk reductions similar in magnitude to selective compounds. In contrast, acetaminophen, a compound with negligible COX-2 activity, produced no significant change in lung cancer risk.

Our results are in general agreement with two recent meta-analyses showing that regular intake of non-selective NSAIDs such as aspirin and ibuprofen reduce the risk of lung cancer [3,4]. These findings coupled with existing preclinical, molecular, and epidemiologic evidence suggest that aberrant induction of COX-2 and up-regulation of the prostaglandin cascade play a significant role in human lung carcinogenesis, and that blockade of this process has strong potential for intervention.

\section{Mechanism(s) of action}

Two primary genes are responsible for the genetic control of cyclooxygenase, a constitutive gene (COX-1) and its inducible isoform (COX-2) [23, 24, 25]. Molecular studies show that the inducible cyclooxygenase-2 gene (COX-2) is over-expressed in virtually every type of human cancer that has been studied including lung cancer [9-11, 26-29]. Metabolism of arachidonic acid via the cyclooxygenase pathway produces various prostaglandins, prostacyclins and thromboxanes, and increased levels have been shown in malignant tumors in comparison to benign tumors and normal tissues [30-34]. Certain prostaglandins, for example PGE2, PGF2-alpha and 6-keto-PGF-1-alpha, are upregulated in association with tumor formation [35]. Both in vitro and in vivo studies have demonstrated that inhibition of the cyclooxygenase pathway, and particularly COX-2, results in the inhibition of tumor growth and development [36-43].

Inhibition of cyclooxygenase and blockade of the prostaglandin cascade may impact upon neoplastic growth and development by reducing key features of carcinogenesis, vis a vis, mutagenesis, angiogenesis, and mitosis, and also by stimulating apoptosis of malignant cells $[44,45,46]$. It has recently been discovered that up-regulation of COX-2 and correlative production of prostaglandin E2 (PGE2) effectively and specifically induces the promoter II region of the cytochrome P-450 gene (CYP-19) which is transcribed and translated into aromatase, the chief enzyme in the biosynthesis of estrogen $[47,48]$. It is well known that estrogen has strong proliferative effects and mitogenic potential, and procedures which reduce estrogen levels or estrogen activity have been associated with decreased risk of breast cancer as well as other malignancies. The COX blocking agents have also been found to activate the peroxisome proliferator-activated receptors (PPAR), ligands which modulate neoplastic transcription in conjunction with upregulation of the prostaglandin cascade [49]. Recent investigations of human cell lines and tissue samples of adenocarcinoma of the lung and of a hamster model of NNK-induced adenocarcinoma reveal overexpression of beta-adrenergic receptors which modulate arachidonic acid release and stimulate carcinogenesis $[12,13$, 14, 15]; notably, these effects are blocked by administration of NSAIDs [12]. These multiple lines of evidence suggest that aberrant induction and upregulation of the prostaglandin cascade play a significant role in carcinogenesis, and that blockade of this process has strong potential for intervention.

\section{COX-2 Controversy}

Celecoxib (Celebrex) and rofecoxib (Vioxx) were approved for the treatment of arthritis by the FDA in 1999. In randomized clinical trials, both compounds demonstrated better gastrointestinal safety and efficacy profiles than their NSAID predecessors [50-54]. Following FDA approval, each of these drugs was routinely prescribed to millions of individuals who suffered from arthritis and other inflammatory condi- 
tions. It was thus unsettling to both patients and prescribing physicians alike when Merck recalled Vioxx from the market due to concerns regarding cardiovascular outcomes [55]. Subsequently, the cardiovascular safety of all selective COX-2 inhibitors has come under scrutiny [56].

Randomized clinical trials (RCTs) have traditionally been the gold standard for unbiased assessment of the risks versus benefits of therapeutic and chemopreventive medications. Extraordinary media coverage has been given to the two RCTs wherein increases were observed in the risk of adverse cardiovascular outcomes with long term intake of well-known selective COX-2-inhibiting agents (rofecoxib and celecoxib) [57, 58 59]. Unfortunately, several potential pitfalls in these investigations have not been explored. These include the following:

1. Dosages of both rofecoxib (Vioxx) and celecoxib (Celebrex) administered in these RCTs were above the standard recommended doses ( 2 and 4 times, respectively, the typical dose used in the treatment of arthritis).

2. Only fixed doses were tested without adjustment according to body size as recommended by the drug manufacturers. Because the therapeutic window of smaller individuals is usually reduced, their dose should have been lowered and safety tolerance checked by measuring individual blood levels.

3. Data of both RCTs were examined by "intention to treat" analysis which assumes that all individuals who were enrolled for study completed the full course of treatment. Since there were substantial losses of subjects to follow-up in both RCTs, this method may have led to unreliable results pertaining to etiologic effects of the compounds.

4. Cox regression analysis was applied in the examination of data; however, the Cox model used incorporated only treatment effects without adjustment for individual cardiovascular risk factors. As a consequence, results may have been influenced by confounding, interaction (effect modification), or both.

5. Since neither RCT was designed to examine cardiovascular outcomes, inclusion of only such outcomes (as opposed to all adverse events) may have compromised probability levels in tests of significance.

Furthermore, focus on these two studies at the exclusion of others has produced misinformation about the cardiovascular safety of individual COX-2 inhibitors. For example, comprehensive meta-analyses of randomized clinical trials find no evidence supporting a general "class effect" of selective COX-2 inhibitors but rather suggest that rofecoxib may increase cardiovascular risk $(60,61,62,63,64)$, blood pressure and renal dysfunction [65] whereas celecoxib does not.

Clearly, future chemopreventive studies should attempt to eliminate sources of bias and accurately elucidate risk versus benefit of the selective COX-2 inhibitors. Comparative studies should be designed to determine the appropriate dose, duration, side effects, and cost-effectiveness of individual compounds. Con- tinued exploration of selective COX-2 inhibitors should be considered a top cancer research priority. Our findings of marked decreases in lung cancer risk with COX-2 blockade underscores the critical need for human clinical investigations of these compounds in order to expedite their efficacious application in the chemoprevention and therapy of cancer. Furthermore, experimental designs of chemopreventive clinical trials should embellish rather than ignore two golden rules of medicine: the dose makes the poison and first do no harm [66].

\section{CONCLUSIONS}

We conducted a case control study to examine the effects of selective COX-2 inhibitors against human lung cancer. Results are summarized below:

1. Daily intake of selective COX-2 inhibitors produced a significant reduction $(60 \%)$ in the risk of human lung cancer.

2. Similar risk reductions were observed for individual COX-2 inhibitors, celecoxib and rofecoxib.

3 . The observed chemopreventive effects were associated with recommended daily doses of celecoxib (median dose $=200 \mathrm{mg}$ ) or rofecoxib (median dose $=25$ $\mathrm{mg})$.

4. Significant risk reductions of similar magnitude were observed for over the counter NSAIDs with non-selective COX-2 activity, such as regular (325mg) aspirin and $(200 \mathrm{mg})$ ibuprofen.

5. Daily intake of baby $(81 \mathrm{mg})$ aspirin produced a marginally significant risk reduction in lung cancer.

6. Acetaminophen, an analgesic without COX-2 activity, did not produce a significant change in the risk of lung cancer.

Notably, selective COX-2 inhibitors (celecoxib and rofecoxib) were only recently approved for use in 1999, and rofecoxib (Vioxx) was withdrawn from the marketplace in 2004. Nevertheless, even in the short window of exposure to these compounds, the selective COX-2 inhibitors produced significant reductions in the risk of lung cancer. These early results tend to substantiate the important role of COX-2 in lung carcinogenesis, and reciprocally, the strong potential for selective COX-2 blockade in lung cancer chemoprevention. Further studies will be required to determine the appropriate dose, frequency of intake, duration, side effects and cost effectiveness of COX-2 inhibitors in the chemoprevention of lung cancer.

\section{ACKNOWLEDGEMENT}

This work was partially supported by a research grant from Pfizer and grant P30 CA16058 from the National Cancer Institute.

\section{CONFLICT OF INTEREST}

The authors have declared that no conflict of interest exists.

\section{REFERENCES}

1. Ahmedin J, Siegel R, Ward E, Murray T, Xu J, Smigal C, Thun MJ. Cancer Statistics, 2006. CA Cancer J Clin, 2006; 56 (2): 106-130. 
2. Harris RE. COX-2 blockade in cancer prevention and therapy: widening the scope of impact. In: Harris RE ed. COX-2 Blockade in Cancer Prevention and Therapy. Totowa, NJ: Humana Press. 2002: 341-365.

3. Harris RE, Beebe-Donk J, Doss H, Burr-Doss D. Aspirin, ibuprofen, and other non-steroidal anti-inflammatory drugs in cancer prevention: a critical review of non-selective COX-2 blockade (review). Oncology Reports, 2005; 13: 559-583.

4. Gonzalez-Perez A, Garcia Rodriquez LA, Lopez-Ridaura R. Effects of non-steroidal anti-inflammatory drugs on cancer sites other than the colon and rectum: a meta-analysis. BMC Cancer, 2003; 3: 1-12.

5. Harris RE, Beebe-Donk J, Alshafie GA. Reduction in the risk of human breast cancer by selective cyclooxygenase-2 (COX-2) inhibitors. BMC Cancer 6: 27, 2006.

6. Schuller HM. The role of cyclooxygenase-2 in the prevention and therapy of lung cancer. In: Harris RE ed. COX-2 Blockade in Cancer Prevention and Therapy. Totowa, NJ: Humana Press. 2002: 99-116.

7. Castonguay A, Rioux N. Inhibition of lung tumorigenesis by sulindac: comparison of two experimental protocols. Carcinogenesis, 1997; 19: 1393-1400.

8. Rioux N, Castonguay A. Prevention of NNK-induced lung tumorigeneis in A/J mice by acteylsalicaylic acid and NS-398. Cancer Res, 1998; 58: 5354-5360.

9. Wolff H, Saukkonen K, Anttila S, Karjalainen A, Vainio H, Ristimaki A. Expression of cyclooxygenase-2 in human lung carcinoma. Cancer Res 1998; 58 (22): 4997-5001.

10. Hida T, Yatabe Y, Achiwa H, Muramatsu H, Kozaki K, Nakamura S, Ogawa M, Mitsudomi T, Sugiura T, Takahashi T. Increased expression of cylcooxygenase 2 occurs frequently in human lung cancers, specifically in adenocarcinomas. Cancer Res, 1999; 59: 198-204.

11. Koki AT, Leahy KM, Harmon JM, Masferrer JL. Cyclooxygenase-2 and cancer. In: Harris RE ed. COX-2 Blockade in Cancer Prevention and Therapy. Totowa, NJ: Humana Press. 2002: 185-204.

12. Schuller HM, Tithof PK, Williams M, Plummer HK III. The tobacco-specific

4-(methylnitrosamino)-1-(3-pyridyl)-1-butanone is a beta-adrenergic agonist and stimulates DNA synthesis in lung adenocarcinoma via beta-adrenergic receptor-mediated release of arachidonic acid. Cancer Research, 1999; 59:4510-4515.

13. Laag E, Majidi M, Cekanova M, Masi T, Takahashi T, Schuller HM. NNK stimulates ERK1/2 and CREB/ATF-1 phosphorylation via beta-1-AR and EGFR signaling in human lung adenocarcinoma and small airway epithelial cells. Int J Cancer, 2006; 119: 1547-1552.

14. Schuller HM, Plummer HK III, Bochsler PN, Dudric P, Bell JL, Harris RE. Co-expression of beta-adrenergic receptors and cyclooxygenase- 2 in pulmonary adenocarcinoma. Int J Oncol, 2001; 19(3): 445-449.

15. Cekanova M, Majidi M, et al. Over-expressed Raf-1 and P-Creb are early markers for lung adenocarcinoma. Cancer 2007; 109: 1164-1173.

16. Peto R, Gray R, Collins R, Wheatley K, Hennekens C, Jamrozik K, Warlow C, Hafner B, Thompson E, Norton S. Randomized trial of prophylactic daily aspirin in British male doctors. $\mathrm{Br}$ Med J (Clin Res Ed) , 1988; 296 (6618): 313-316.

17. Schreinemachers DM, Everson RB. Aspirin use and lung, colon, and breast cancer incidence in a prospective study. Epidemiology, 1994; 5:138-146.

18. Harris RE, Beebe-Donk J, Schuller HM. Chemoprevention of lung cancer by nonsteroidal anti-inflammatory drugs among cigarette smokers. Oncology Reports, 2002; 9: 693-695.

19. Muscat JE, Chen SQ, Richie JP JR, Altorki NK, Citron M, Olson S, Neugut AI, Stellman SD. Risk of lung carcinoma among users of nonsteroidal anti-inflammatory drugs. Cancer, 2003; 97(7): 1732-1736.

20. Walter SD. Determination of significant relative risks and optimal sampling procedures in prospective and retrospective comparative studies of various sample sizes. Am J Epidemiol 1977; 105:387-397.

21. Schlesselman JJ. Case Control Studies: Design, Conduct, Analysis. New York, NY : Oxford University Press, 1982.

22. Harrell F. Logistic Regression Procedure. Statistical Analysis System (SAS). 2005.

23. Vane JR. Inhibition of prostaglandin synthesis as a mechanism of action for aspirin-like drugs. Nature, 1971; 231: 323-235.

24. Herschman HR. Regulation of prostaglandin synthase- 1 and prostaglandin synthase-2. Cancer and Metas Rev, 1994; 13: 241-256

25. Hla $\mathrm{T}$ and Neilson K. Human cyclooxygenase-2 cDNA. Proc Natl Acad Sci USA, 1992; 89:7384-7388.

26. Eberhart CE, Coffey RJ, Radhika A, Giardiello FM, Ferrenbach $\mathrm{S}$, Dubois RN. Up-regulation of cycloxygenase-2 gene expression in human colorectal adenomas and adenocarcinomas. Gastroenterology, 1994; 107: 1183-1188.

27. Parrett ML, Harris RE, Joarder FS, Ross MS, Clausen KP, Robertson FM. Cyclooxygenase-2 gene expression in human breast cancer. International Journal of Oncology, 1997; 10:503-507

28. Masferrer JL, Leahy KM, Koki AT, Aweifel BS, Settle SL, Woerner BM, Edwards DA, Flickinger AG, Moore RJ, Seibert K. Antiangiogenic and antitumor activities of cyclooxygenase-2 inhibitors. Cancer Res, 2000; 60(5): 1306-1311.

29. Sano H, Kawahito Y, Wilder R, Hashiramoto A, Mukai S, Asai K, Kimura S, Kato H, Kondo M, Hla T. Expression of cyclooxygenase-1 and -2 in human colorectal cancer. Cancer Res, 1995; 55: 3785-3789.

30. El-Bayoumy K. Evaluation of chemoprevention agents against breast cancer and proposed strategies for future clinical intervention trials. Carcinogenesis, 1994; 15 (11): 2395-2420.

31. Bennett A, Tacca MD, Stamford IF, Zebro T. Prostaglandins from tumors of human large bowel. Br J Cancer, 1977; 35:881-4.

32. Bennett A, Civier A, Hensby CN, et al. Measurement of arachidonate and its metabolities extracted from human normal and malignant gastrointestinal tissues. Gut, 1987; 28:315-8.

33. Narisawa T, Kusaka H, Yamazaki Y, Takahashi M, Koyama H, Koyama K, et al. Relationship between blood plasma prostaglandin $\mathrm{E}_{2}$ and liver and lung metastases in colorectal cancer. Dis Colon Rectum, 1990; 33:840-5.

34. Rolland PH, Martin PM, Jacquemier J, Rolland AM, Toga M. Prostaglandins in human breast cancer: evidence suggesting that an elevated prostaglandin production is a marker of high metastatic potential for neoplastic cells. J Natl Cancer Inst, 1980; 64 (5): 1061-70.

35. Kort WJ, Bijma AM, van Dam JJ, vd Ham AC, Hekking JM, Ingh HF, Meijer WS, van Wilgenburg MGM, Zijlstra FJ. Eicosanoids in breast cancer patients before and after mastectomy. Prostaglandins Leukotrienes and Essential Fatty Acids, 1991, 45: 319-327.

36. Ara G, Teicher BA. Cyclooxygenase and lipoxygenase inhibitors in cancer therapy. Prostagland, Leuk and Essent Fatty Acids, 1996; 54: 3-16.

37. Kelloff GJ, Johnson JR, Crowell JA, Boone CW, DeGeorge JJ, Steele VE, Mehta MU, Temeck JW, Schmidt WJ, Burke G, Greenwald P, Temple RJ. Guidance for development of chemopreventive agents, Clinical Development Plan: Aspirin. J Cellular Biochemistry, 1994; (Suppl 20): 74-83.

38. Greenwald P. Chemoprevention of cancer. Scientific American, 1996; 275(3): 96-100.

39. Greenwald P, Kelloff G, Burch-Whitman C, Kramer BS. Chemoprevention. CA Cancer Journal for Clinicians, 1995; 45(1): 
31-49.

40. Boone CW, Kelloff GJ, Steele VE. Natural history of intraepithelial neoplasia in humans with implications for cancer chemopreventive strategy. Cancer Res, 1992; 52(7): 1651-1659.

41. Eberhart CE, Dubois RN. Eicosanids and the gastrointestinal tract. Gastroenterology, 1995; 109: 285-301.

42. Mitchell JA, Akarasereenont P, Thiemermann C, Flower RJ, Vane JR. Selectivity of nonsteroidal anti-inflammatory drugs as inhibitors of constitutive and inducible cyclooxygenase. Proc Natl Acad Sci USA, 1994; 90: 11693-11697.

43. Marnett LJ. Aspirin and the potential role of prostaglandins in colon cancer. Cancer Res, 1992; 52: 5575-5589.

44. Shiff SJ, Rigas B. The role of cyclooxygenase inhibition in the antineoplastic effects of nonsteroidal anti-inflammatory drugs (NSAIDs). J Exp Med, 1999; 190: 445-450.

45. Howe LR, Subbaramaiah K, Brown AMC, Dannenberg AJ. Cyclooxygenase-2: a target for the prevention and treatment of breast cancer. Endocrine-Related Cancer, 2001; 8: 97-114.

46. Harris RE, Robertson FM, Farrar WB, Brueggemeier RW. Genetic induction and upregulation of cyclooxygenase (COX) and aromatase (CYP-19): an extension of the dietary fat hypothesis of breast cancer. Medical Hypotheses, 1999; 52 (4): 292-293.

47. Zhao Y, Agarwal VR, Mendelson CR, Simpson ER. Estrogen biosynthesis proximal to a breast tumor is stimulated by PGE2 via cyclic AMP, leading to activation of promoter II of the CYP19(aromatase) gene. Endocrinology, 1996; 137(12): 5739-5742.

48. Brueggemeier RW, Quinn AL, Parrett ML, Joarder FS, Harris $\mathrm{RE}$, Robertson FM. Correlation of aromatase and cyclooxygenase gene expression in human breast cancer specimens. Cancer Letters, 1999; 140 (1-2):27-35.

49. Lehmann JM, Lenhard Jm, Oliver BB, Ringold GM, Kliewer SA. Perioxisome proliferator-activated receptors alpha and gamma are activated by indomethacin and other nonsteroidal anti-inflammatory drugs. J Biol Chem, 1997; 272(6): 3406-3410.

50. Bombardier C. Laine L, Reicin A, Shapiro D. Burgo-Vargas R, Davis B, Day R, Ferraz MB, Hawkey CJ, Hochberg MC, Kvien TK, Schuitzer TJ: VIGOR Study Group. Comparison of upper gastrointestinal toxicity of rofecoxib and naproxen in patients with rheumatoid arthritis. N Engl J Med, 2000; 343 (21): 1520-1528.

51. Silverstein FE, Faich G, Goldstein JL, Simon LS, Pincus T, Whelton A, Makuch R, Eisen G, Agrawal NM, Stenson WF, Burr AM, Zhao WW, Kent JD, Lefkowith JB, Verburg KM, Geis GS. Gastrointestinal toxicity with celecoxib vs nonsteroidal anti-inflammatory drugs for osteoarthritis and rheumatoid arthritis: the CLASS study: a randomized controlled trial. Celecoxib Long-term Arthritis Safety Study. JAMA, 2000; 284 (10): 1247-1255.

52. Simon LS, Weaver AL, Graham DY, Kivitz AJ, Kipsky PE, Hubbard RC, Isakson PC, Verburg KM, Yu SS, Zhao WW, Geis GS. Anti-inflammatory and upper gastrointestinal effects of celecoxib in rheumatoid arthritis. Journal of the American Medical Association, 1999; 282: 1921-1928.

53. Langman MJ, Jensen DM, Watson DJ, Harper SE, Zhao PL, Quan H, Bolognese JA, Simon TJ. Adverse upper gastrointestinal effects of rofecoxib compared with NSAIDs. Journal of the American Medical Association, 1999; 282: 1929-1933.

54. Shah AA, Thjodleifsson B, Murray FE, Kay E, Barry M, Sigthorsson G, Gudjonsson H, Oddsson E, Price AB, Fitzgerald DJ, Bjarnason I. Selective inhibition of COX-2 in humans is associated with less gastrointestinal injury: a comparison of nimesulide and naproxen. Gut, 2001; 48 (3): 339-346.

55. Mukherjee D, Nissen SE, Topol EJ. Risk of cardiovascular events associated with selective COX-2 inhibitors. JAMA, 2001; 286 (8): 954-959.

56. Couzin J. Withdrawal of Vioxx casts a shadow over COX-2 inhibitors. Science 2004, 306: 384-385.

57. Bresalier RS, Sandler RS, Quan H, Bolognese JA, Oxenius B, Horgan K, Lines C, Riddell R, Morton D, Lanas A, Konstam MA, Baron JA. Cardiovascular events associated with rofecoxib in a colorectal adenoma chemoprevention trial. N Engl J Med 2005, 352 (11): 1092-1102.

58. Solomon SD, McMurray JJ, Pfeffer MA, Wittes J, Fowler R, Finn $\mathrm{P}$, Anderson WF, Zauber A, Hawk E, Bertagnolli M. Cardiovascular risk associated with celecoxib in a clinical trial for colorectal adenoma prevention. N Engl J Med 2005, 352 (11): 1071-1080.

59. Couzin J. Clinical Trials: Nail-biting time for trials of drugs. Science 2004, 306: 1673-1675.

60. White WB, Faich G, Whelton A, Maurath C, Ridge NJ, Verburg KM, Geis GS, Lefkowith JB. Comparison of thromboembolic events in patients treated with celecoxib, a cyclooxygenase-2 specific inhibitor, versus ibuprofen or diclofenac. Am J Cardiol, 2002; 89 (4): 425-430.

61. White WB, Faich G, Borer JS, Makuch RW. Cardiovascular thrombotic events in arthritis trials of the cyclooxygenase- 2 inhibitor, celecoxib. Am J Cardiol, 2003; 92 (4): 411-418.

62. White WB, West CR, Borer JS, Gorelick PB, Lavange L, Pan SX, Weiner MD, Verburg KM. Risk of cardiovascular events in patients receiving celecoxib: a meta-analysis of randomized clinical trials. American J Cardiology, 2007; 99(1):91-98.

63. Hernandez-Diaz S, Varas-Lorenzo C, Garcia Rodriquez LA. Nonsteroidal anti-inflammatory drugs and the risk of acute myocardial infarction. Basic \& Clinical Pharmacology \& Toxicology, 2006; 98: 266-274.

64. McGettigan P, Henry D. Cardiovascular risk and inhibition of cyclooxygenase: a systematic review of the observational studies of selective and nonselective inhibitor inhibitors of cyclooxygenase 2. JAMA, 2006; 296(13):1633-44.

65. Zhang J, Ding EL, Song Y. Adverse effects of cyclooxygenase-2 inhibitors on renal and arrhythmia events: meta-analysis of randomized trials. JAMA, 2006; 296(13): 1619-1632.

66. Harris RE. Does the dose make the poison? Science, 2005; 308 : 203. 